\title{
Compliance with Summer Thermal Comfort Requirements in Apartment Buildings
}

\author{
Raimo Simson ${ }^{1}$, Jarek Kurnitski ${ }^{2}$, Mikk Maivel ${ }^{3}$, Targo Kalamees ${ }^{4}$, \\ ${ }^{1-4}$ Tallinn University of Technology
}

\begin{abstract}
In this study we have investigated the compliance with summer thermal comfort requirements of 16 new apartment buildings in Estonia by modelling and simulating dwellings using energy and indoor climate simulation software IDA-ICE. We also conducted field measurements of indoor temperature in 17 dwellings in 16 different apartment buildings during the period from 1 July to 31 August 2014. It has been found that $81.3 \%$ of the simulated buildings do not comply with the requirements. Measurements show that overheating can be a problem in apartment buildings also in cold climate regions.
\end{abstract}

Keywords - building simulation, field study, overheating, compliance

\section{INTRODUCTION}

With the goals to cut Europe's primary energy consumption by $20 \%$, the Energy Performance of Buildings Directive 2010/31/EU (EPBD) [1] has been launched to reduce the energy consumption of building sector by obligating Member States to impose requirements for buildings energy efficiency to ensure that by 2021 all new buildings are designed as nearly zero-energy buildings. As one of the priorities, it is stated that even with lower energy usage, good indoor climate must be provided, including summer thermal comfort by avoiding overheating.

In buildings without mechanical cooling, such as typical apartment buildings with improved air tightness, higher levels of insulation and large glazing areas, achieving acceptable indoor temperatures during warm periods is problematic even in cold climate regions [2].

Overheating problems in dwellings have been studied extensively in the UK. [3], [4]. It has been found that increased thermal insulation can increase the risk of overheating and the best ways to avoid high indoor temperatures is to use façade shading elements and sufficient ventilation.

During the last five years there have been several largescale studies carried out in Estonia on residential building stock technical condition and indoor climate, mostly involving buildings built before the 1990s, but also on newer buildings with construction years between 1990 and 2010 [5]. It has been found that indoor temperatures exceed the criterion of weighted excess degree hours above $+27{ }^{\circ} \mathrm{C}$ in $63 \%$ of the studied dwellings.

Maivel et al. studied summer thermal comfort related problems in old and new apartment buildings in Estonia and found that overheating is most probable in new buildings [6]. It was also concluded that for a detailed analysis dynamic indoor climate simulations are needed.
All buildings in Estonia that have acquired construction permit after the year 2009 have to comply with regulation No. 68 "Minimum requirements for energy performance" [7] that also regulates verification of summer thermal comfort compliance in buildings. For apartment buildings with no active cooling measures, the requirement is defined as hourlyaverage indoor temperature excess maximum limit of 150 degree-hours $\left({ }^{\circ} \mathrm{Ch}\right)$ over $+27{ }^{\circ} \mathrm{C}$ during the summertime period from 1 June to 31 August. For compliance assessment, detailed procedure is described in regulation No. 63 "Methodology for calculating the energy performance of buildings" [8]. Temperature calculations are needed for typical living rooms and bedrooms that are most likely to counter overheating. Such rooms are usually south or west oriented and/or have relatively large glazing areas without external or internal shading elements [8]. The verification is to be conducted considering rooms as single zones and by using building simulation software or simplified methods, e.g. graphs.

In this study, we have conducted field measurements of indoor temperature in 17 dwellings in 16 different apartment buildings during the period from 1 July to 31 August 2014.

For summer thermal comfort compliance assessment of the studied buildings, we simulated indoor temperatures in chosen dwellings most likely to counter overheating problems. We used indoor environment and energy simulation software IDAICE and climatic data from the Estonian Test Reference Year with input parameters for internal heat loads and usage profiles as defined in Estonian regulation No. 63 "Methodology for calculating the energy performance of buildings" [8]. In total, 75 dwellings in 16 buildings were simulated.

\section{METHODOLOGY}

\section{A. Climate data}

Summer thermal comfort compliance verification of buildings was assessed according to the requirements described in Estonian regulations No. 63, "Minimum requirements of energy performance" [7] and No. 68, "Methodology for calculating the energy performance of buildings" [8]. Room temperature calculation was performed regardless of the location of the building using the Estonian Test Reference Year (TRY) [9]. The TRY is constructed by using different months from three decades (1970-2000) of climatic data that best describe the Estonian climate. It 
contains hourly-average data of outdoor temperature, relative humidity, wind speeds and solar radiation.

The indoor temperature measurements in dwellings were conducted in the summer of 2014 .

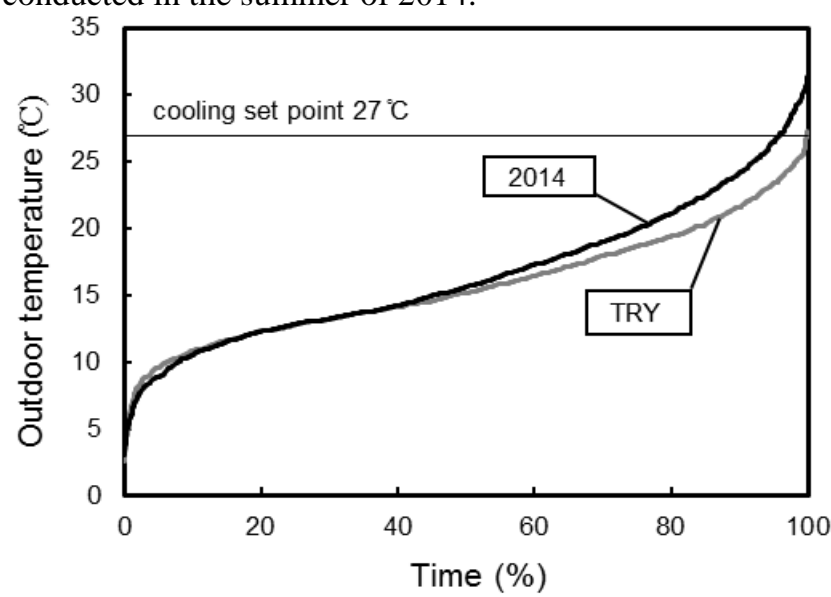

Fig. 1. Hourly-average outdoor temperature duration curves for the period from 1 July to 31 August, a comparison between summer of 2014 (data from Estonian Weather Service, EMHI) and Estonian Test Reference Year (TRY) [9].

Compared to outdoor temperatures from TRY (Fig. 1), the 2014 summer period was relatively warm with two distinctive heat waves with hourly-average outdoor temperatures reaching higher than $30^{\circ} \mathrm{C}$ (Fig. 2.). The temperature excess of degree-hours over $+27{ }^{\circ} \mathrm{C}$ in 2014 was $157.3^{\circ} \mathrm{Ch}$, whereas in case of TRY the temperature excess is $0.5^{\circ} \mathrm{Ch}$ (Fig. 1).

\section{B. Description of the studied buildings}

The studied apartment buildings were selected randomly with the criterion of built year 2009 or later. The buildings varied in terms of architectural design, envelope construction type, glazing areas and window types, geometry, height, location, orientation, etc.

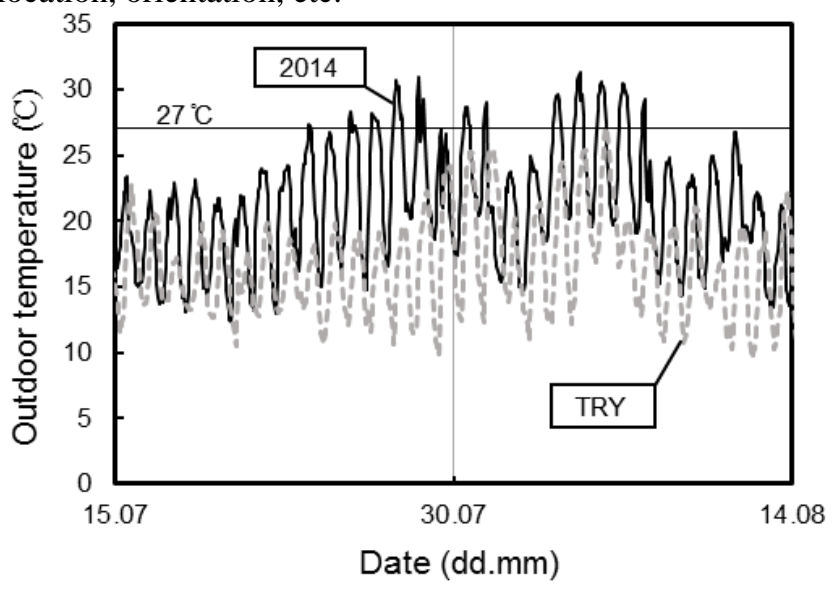

Fig. 2. Heat waves in June and August 2014. Measured hourly-average outdoor temperatures (data from Estonian Weather Service, EMHI) compared to data from TRY [9].

Most of the buildings were designed with precast or monolithic concrete structures with more than four floors above ground (Table 1).

Dwelling sizes varied in large numbers - the floor area of the largest living room was $45.7 \mathrm{~m}^{2}$ and the smallest -12.8 $\mathrm{m}^{2}$; bedroom sizes were between $28.9 \mathrm{~m}^{2}$ and $6.5 \mathrm{~m}^{2}$.

The studied buildings were designed either with central mechanical exhaust ventilation system or de-central mechanical supply-exhaust system with apartment based air handling units (AHU-s). In case of the mechanical exhaust systems, outdoor air was supplied to the dwellings trough fresh air valves, located in external walls, or through window integrated air valves.

TABLE I

SPECIFICATION AND INPUT DATA USED IN SIMULATIONS

\begin{tabular}{|c|c|c|c|c|c|c|c|c|c|}
\hline \multirow{2}{*}{$\begin{array}{l}\text { Building } \\
\text { no }\end{array}$} & \multirow{2}{*}{$\begin{array}{l}\text { Building structure } \\
\text { type }\end{array}$} & \multicolumn{3}{|c|}{ Thermal transmittance of envelope part, $\mathrm{W} /(\mathrm{m} 2 \cdot \mathrm{K})$} & \multirow{2}{*}{$\begin{array}{l}\text { Windows } \\
\text { solar } \\
\text { factor, } \\
\text { (SHGC) }\end{array}$} & \multirow{2}{*}{ Ventilation system type } & \multirow{2}{*}{$\begin{array}{l}\text { Building } \\
\text { height, } \\
\mathrm{m}\end{array}$} & \multirow{2}{*}{$\begin{array}{l}\text { Floors } \\
\text { above } \\
\text { ground }\end{array}$} & \multirow{2}{*}{$\begin{array}{l}\text { Infiltration } \\
1 /(\mathrm{s} \cdot \mathrm{m} 2) \\
\text { ext. surf. }\end{array}$} \\
\hline & & Ext. wall & Roof & Windows & & & & & \\
\hline B1 & Wood-frame & 0.21 & 0.16 & 1.06 & 0.68 & Mech. exhaust & 10.6 & 4 & 0.042 \\
\hline B2 & Wood-frame & 0.17 & 0.14 & 0.63 & 0.55 & Mech. supply-exhaust & 11.0 & 4 & 0.042 \\
\hline B3 & L/W concrete blocks & 0.16 & 0.14 & 1.10 & 0.69 & Mech. exhaust & 12.0 & 4 & 0.042 \\
\hline B4 & Concrete & 0.15 & 0.17 & 1.14 & 0.71 & Mech. exhaust & 26.5 & 10 & 0.056 \\
\hline B5 & L/W concrete blocks & 0.18 & 0.12 & 1.10 & 0.65 & Mech. supply-exhaust & 19.3 & 6 & 0.056 \\
\hline B6 & Concrete & 0.24 & 0.14 & 1.00 & 0.40 & Mech. supply-exhaust & 18.5 & 6 & 0.056 \\
\hline B7 & Concrete & 0.24 & 0.14 & 1.00 & 0.40 & Mech. supply-exhaust & 18.5 & 6 & 0.056 \\
\hline B8 & Precast concrete & 0.17 & 0.09 & 0.60 & 0.48 & Mech. exhaust & 21.0 & 6 & 0.056 \\
\hline B9 & Precast concrete & 0.17 & 0.14 & 0.89 & 0.60 & Mech. exhaust & 14.0 & 4 & 0.042 \\
\hline B10 & Precast concrete & 0.23 & 0.16 & 1.20 & 0.63 & Mech. supply-exhaust & 24.9 & 7 & 0.056 \\
\hline B11 & Concrete & 0.16 & 0.14 & 1.10 & 0.69 & Mech. exhaust & 21.5 & 6 & 0.056 \\
\hline B12 & Concrete & 0.22 & 0.15 & 1.00 & 0.70 & Mech. supply-exhaust & 17.0 & 5 & 0.056 \\
\hline B13 & Precast concrete & 0.23 & 0.16 & 1.10 & 0.67 & Mech. supply-exhaust & 25.1 & 7 & 0.056 \\
\hline B14 & Wood-frame & 0.25 & 0.17 & 1.40 & 0.70 & Mech. exhaust & 8.3 & 2 & 0.035 \\
\hline B15 & Precast concrete & 0.21 & 0.12 & 1.65 & 0.63 & Mech. supply-exhaust & 12.0 & 3 & 0.042 \\
\hline B16 & Precast concrete & 0.21 & 0.12 & 1.50 & 0.63 & Mech. supply-exhaust & 12.0 & 3 & 0.042 \\
\hline
\end{tabular}


As of passive cooling techniques, in one of the buildings glazing with low solar heat gain coefficient $(\mathrm{SHGC}=0.4)$ for south-west oriented façade was used, one of the studied apartment had internal venetian blinds and in some cases the use of balconies as shading elements was identified. Other intentional measures, such as external window shading, were not registered. Also, no active cooling measures were used.

The thermal transmittances of the building envelope were between 0.15 and $0.25 \mathrm{~W} /\left(\mathrm{m}^{2} \cdot \mathrm{K}\right)$ for external walls, $0.09 \div$ 0.17 for roofs and $0.60 \div 1.65 \mathrm{~W} /\left(\mathrm{m}^{2} \cdot \mathrm{K}\right)$ for windows. The SHGC-s of the windows for different buildings varied from 0.40 to 0.71 .

\section{Measurements}

Indoor temperature measurements were carried out during the period from 1 July to 31 August in 17 dwellings in 16 different apartment buildings. Apartments were chosen by estimation of most likely to counter overheating, e.g. with south or west orientation, located on higher floors, relatively large glazing areas, etc. For measurements previously calibrated data logging Hobo U12 devices were used with temperature measuring range of -20 to $+70{ }^{\circ} \mathrm{C}$ with accuracy $\pm 0.35^{\circ} \mathrm{C}$ and relative humidity 5 to $95 \%$ with accuracy $\pm 2.5 \%$ of full scale output. The data loggers were placed in the occupied zone of the rooms so that they would not be affected by direct sunlight, ventilation air flows, heat generating equipment, etc. An example of the data logger placement is seen in Fig. 3.

\section{Simulations}

In order to determine overheating risk of dwellings and for assessing the apartment buildings compliance with summer thermal comfort, building simulations were used. The buildings were modelled with indoor climate and energy simu-

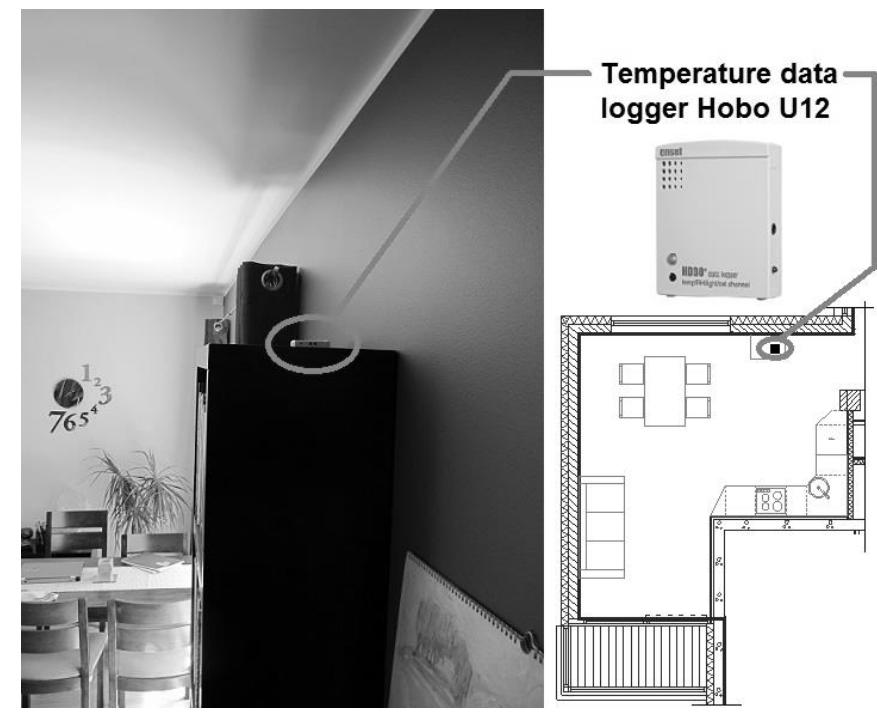

Fig. 3. Example placement of a temperature data logger Hobo U12 used in room temperature measurements, photo of the studied dwelling (left) and room plan (right). lation software IDA Indoor Climate and Energy, version 4.6.1 (IDA-ICE) [10]. This tool allows detailed and dynamic wholeyear multi-zone building simulations of indoor climate, energy consumption and building systems performance. The software has been validated according to European Standard CEN 13791 ,Thermal Performance of Buildings - Calculation of Internal Temperatures of a Room in summer without Mechanical Cooling - General Criteria and Validation Procedures" defined test cases [11].

Input data for the studied buildings, including building site surroundings, architecture, floor plans, and specifications of walls, roofs and windows were acquired from design documentation of the buildings, Estonian Registry of Buildings database [12] and Estonian Land Board web map [13].

The U-values of external boundaries were calculated automatically in IDA-ICE by defining the material layers with appropriate parameter values for thermal conductivity. Each material layer also included properties for specific heat and density for accurate calculation of building thermal mass. Solar heat gain coefficients of windows, if not available in design documentation, were calculated using detailed window model with glazing properties calculation tool in IDA-ICE (Fig. 4). Overall values used in building simulations are shown in Table 1.

Trees close to the buildings, which would cast shadows, were modelled as crossing vertical rectangular planes (Fig. 5). The shading effect of foliage was estimated as transparency factor between 0.2 and 0.3 (with 1.0 being fully transparent) [14].

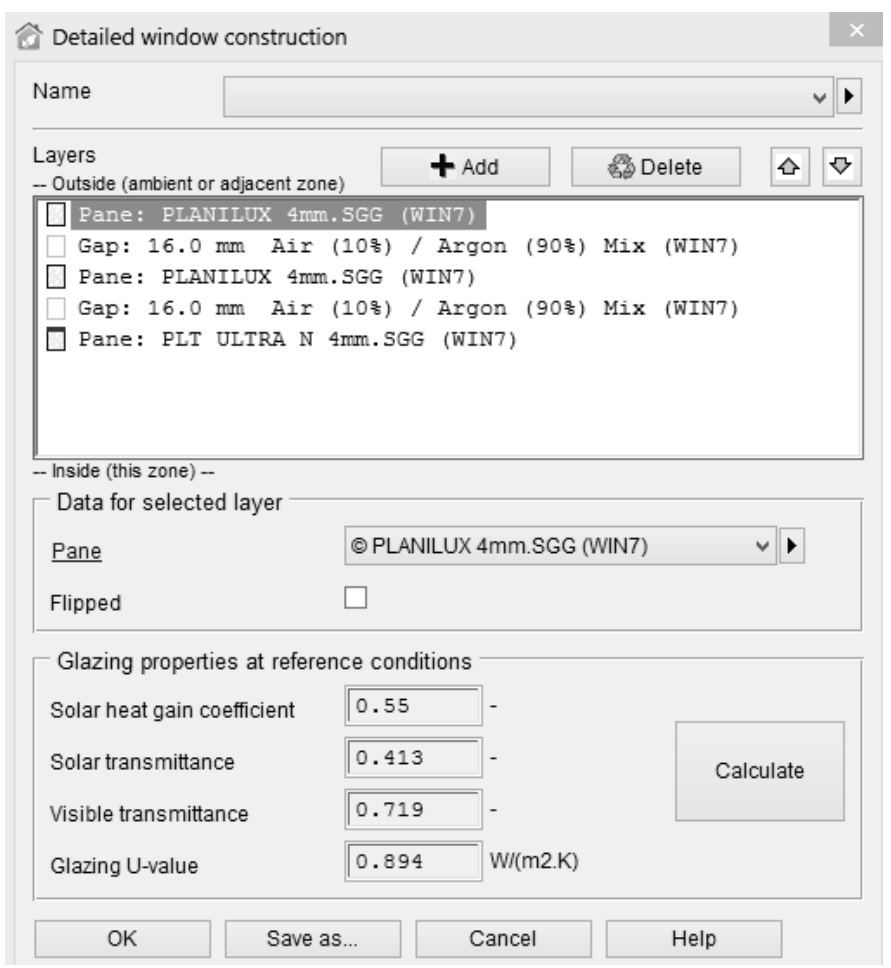

Fig. 4. Detailed window glazing properties calculation tool in IDA-ICE. 

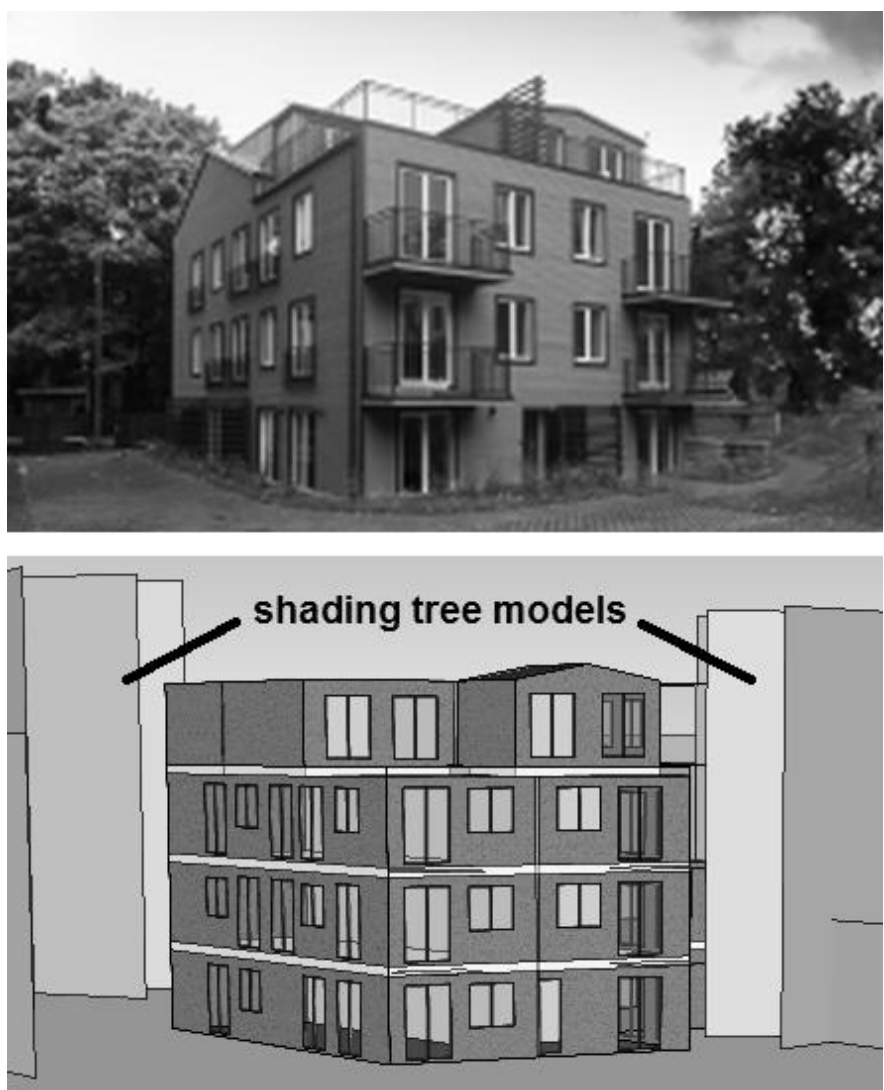

Fig. 5. Example of a modelled building and shading elements. Photo of the building (top) and simulation model (bottom).

As no data for air tightness of the studied buildings was available, infiltration for every building was calculated using equation (1):

$$
\mathrm{q}_{\mathrm{i}}=\frac{\mathrm{q}_{50}}{3,6 \times \mathrm{x}} \mathrm{A}
$$

where

$\mathrm{q}_{50}$ - building air permeability at $50 \mathrm{~Pa}$ pressure difference, $\mathrm{m}^{3} /\left(\mathrm{h} \cdot \mathrm{m}^{2}\right)$

A - total area of building envelope, $\mathrm{m}^{2}$;

$\mathrm{x}$ - building height factor: 35 for one, 24 for two, 20 for three and four and 15 for five and higher story buildings [8]. In all cases, building air permeability value $3 \mathrm{~m}^{3} /\left(\mathrm{h} \cdot \mathrm{m}^{2}\right)$ was used, as defined for calculations of new buildings in [8].

The opening and closing of windows was modelled using on/off temperature control macro with a dead band of $2{ }^{\circ} \mathrm{C}$ (Fig. 6). This means that windows would open, when room temperature raised $1{ }^{\circ} \mathrm{C}$ above the set point temperature value, and close, when it dropped $1{ }^{\circ} \mathrm{C}$ under the set point value. In this case the set point was chosen $+22^{\circ} \mathrm{C}$, ensuring window openings at $+23{ }^{\circ} \mathrm{C}$, and closings at room temperatures under $+21{ }^{\circ} \mathrm{C}$. When outdoor temperature would exceed indoor temperature values, the windows would also close (Fig. 5). The openable area was set to $10 \%$ of the window's total area, imitating the airing position of the window.

Internal heat gains for dwellings were used according to regulation No. 63 [8]: $28.3 \mathrm{~m}^{2}$ floor area per occupant with

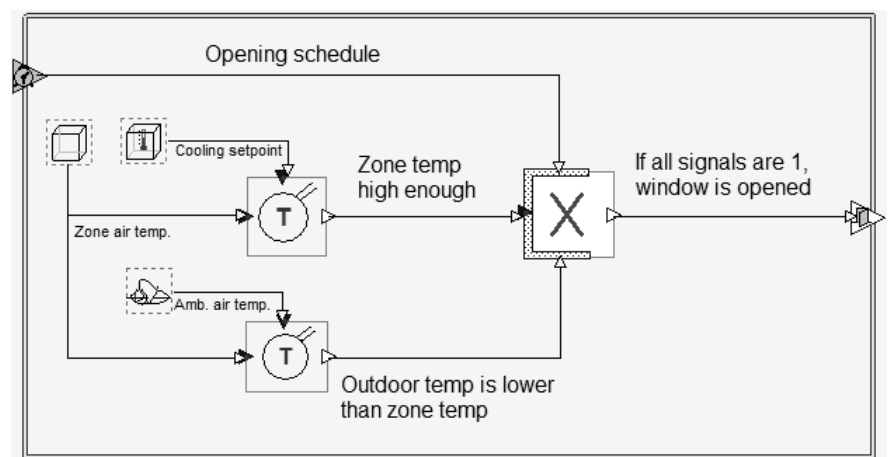

Fig. 6. Window opening control macro in IDA-ICE used in simulations. Window opens if zone temperature exceeds cooling setpoint $t_{\text {cool }}+\Delta t / 2$, and outdoor temperature is lower than room temperature. Window closes when the zone temperature drops below $\mathrm{t}_{\text {cool }}-\Delta \mathrm{t} / 2 . \Delta \mathrm{t}$ is defined as dead band value.

(a)

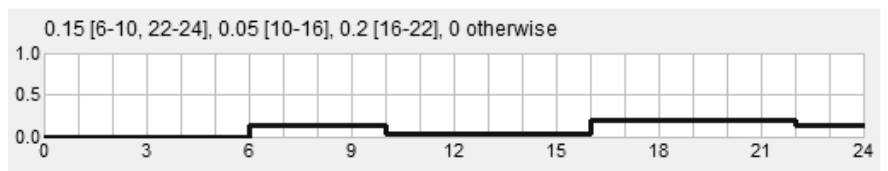

(b)

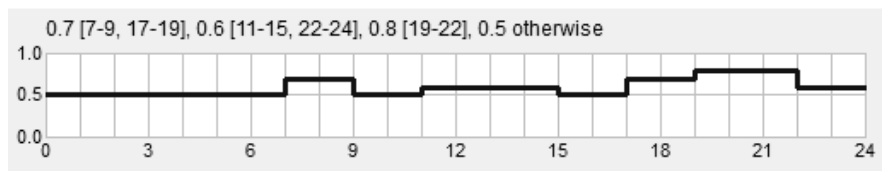

(c)

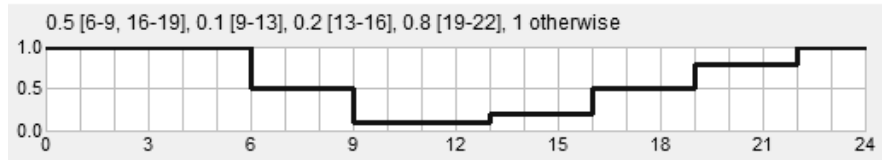

Fig. 7. IDA-ICE plot of hourly profiles for lighting (a), equipment (b) and occupancy (c) used for internal heat gains calculation according to Estonian regulation No. 63 [8].

heat emission of $125 \mathrm{~W}$, incl. $85 \mathrm{~W}$ sensible heat; equipment 3 $\mathrm{W} / \mathrm{m}^{2}$ and lighting $8 \mathrm{~W} / \mathrm{m}^{2}$. Daily presence and load profiles were applied to the models as described in Fig. 7.

Ventilation in dwellings was modelled with constant airflow rate of $0.5 \mathrm{l} /\left(\mathrm{s} \cdot \mathrm{m}^{2}\right)$ [7]. In apartments with central mechanical exhaust ventilation, the supply air temperature was taken equal to outdoor temperature. In apartments with local AHU-s, supply air temperature was considered $1{ }^{\circ} \mathrm{C}$ higher than outdoor temperature due to the supply fan heat emission. Considering the bypass option of domestic AHU-s, heat exchanger effect was not accounted for.

\section{RESULTS AND DISCUSSION}

\section{A. Measurements results}

The field measurement results of indoor temperature in dwellings are presented in Fig.8. It is shown that in some cases temperatures over $+30^{\circ} \mathrm{C}$ are experienced. It can be seen that most of the periods with temperatures over $+27^{\circ} \mathrm{C}$ occur at the end of July and at the beginning of August during the warmer 


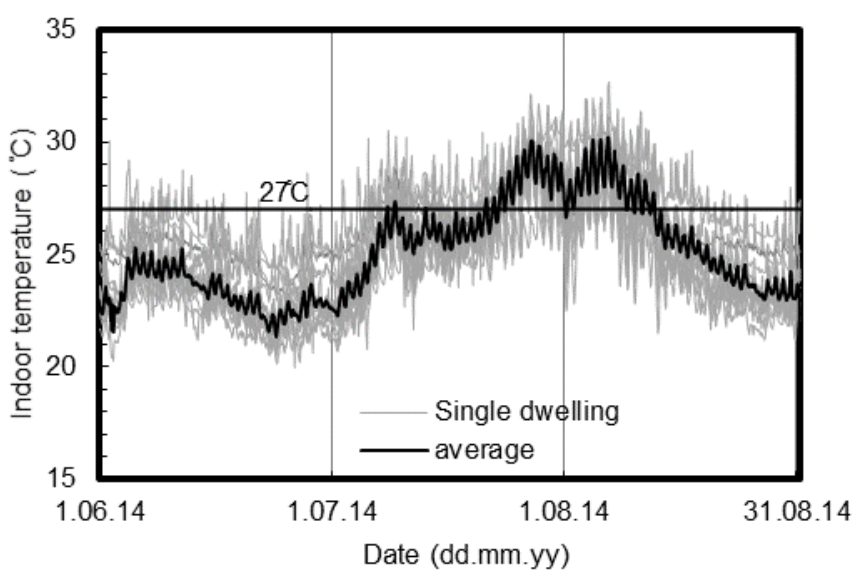

Fig. 8. Measured hourly-average indoor temperatures during period of 1 . June -31 . August 2014 in studied dwellings.

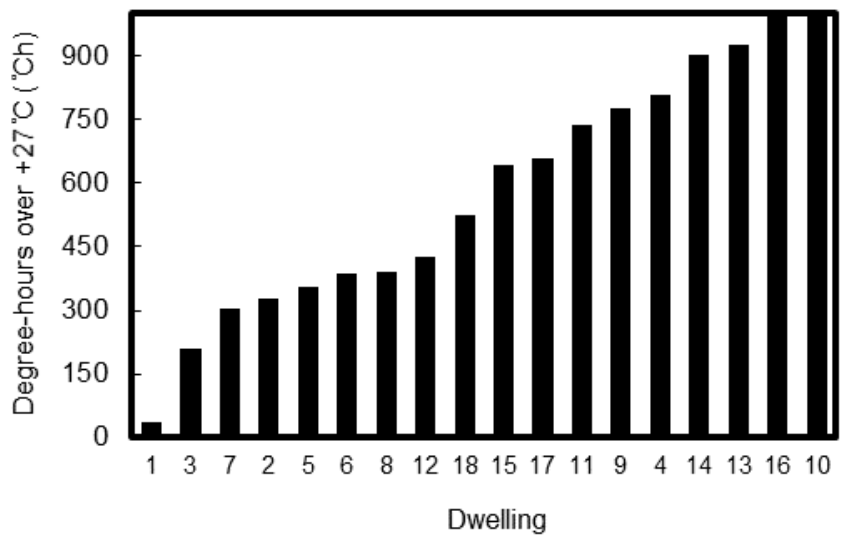

Fig. 9. Measured indoor temperature excess in degree-hours over $27^{\circ} \mathrm{C}$ in selected living rooms and bedrooms in studied apartment buildings during the period from 1 July to 31 August 2014.

summer periods with outside air temperatures reaching $+30^{\circ} \mathrm{C}$ (Fig. 2).

The temperature excess of degree-hours over $27^{\circ} \mathrm{C}$ during the measurement period exceeds the 150 value in $94 \%$ of the dwellings (Fig. 9). Highest excess values were measured in dwellings No 16 and 10 , with $2,110{ }^{\circ} \mathrm{Ch}$ and $1,053{ }^{\circ} \mathrm{Ch}$ respectively.

\section{B. Simulations results}

From the total of 75 simulated dwellings, 31 reached higher values than $150^{\circ} \mathrm{Ch}$ of indoor temperature excess over $+27^{\circ} \mathrm{C}$. In some buildings the limit value was exceeded in only one typical dwelling, for example in building B4, where temperature excess was over $700{ }^{\circ} \mathrm{Ch}$ in the living room and no set point exceeding was registered in the bedroom.

In several cases the temperature excess was either very close or slightly over the limit. "Worst cases" for bedrooms and living rooms from each building are shown separately in Fig. 10 .

The highest values were reached in both room types in the same building with over $1,000{ }^{\circ} \mathrm{Ch}$ in the living room and nearly $750^{\circ} \mathrm{Ch}$ in the bedroom.

Altogether in 13 out of 16 simulated buildings temperature excess in dwellings exceeded the limit value. (a)

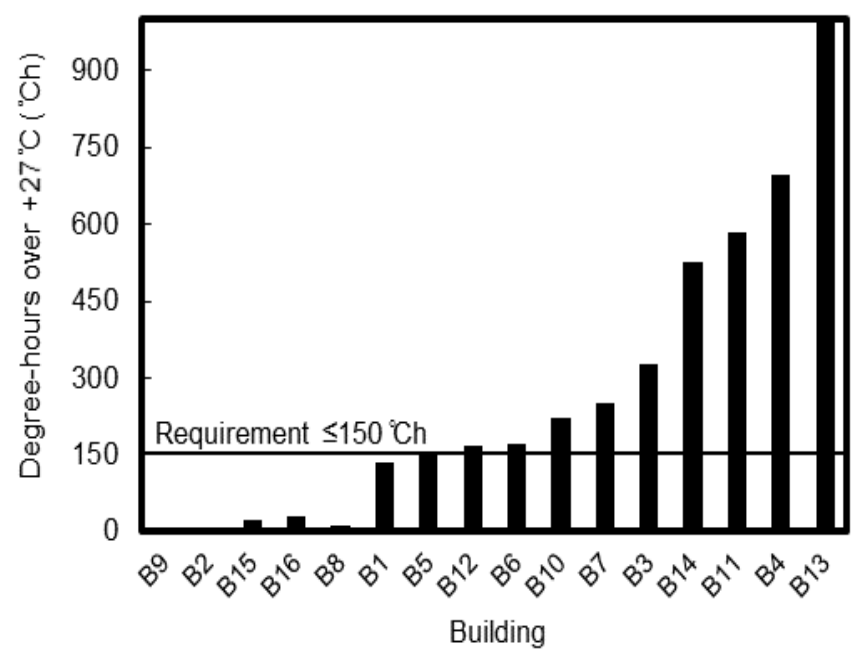

(b)

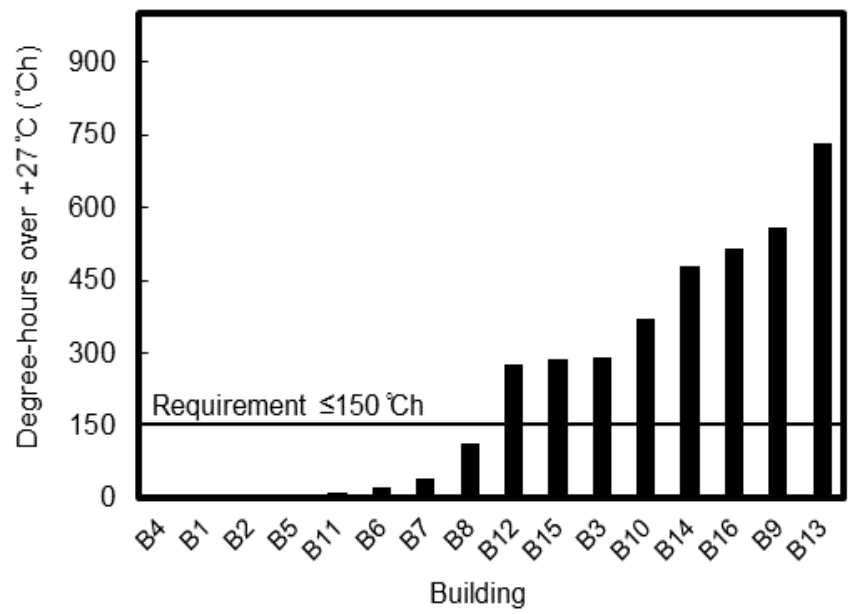

Fig. 10. Simulated hourly-average room temperature excess in degree-hours over $27^{\circ} \mathrm{C}$ in "worst case" living rooms (a) and bedrooms (b) in studied apartment buildings during the period from 1 July to 31 August. Requirement for compliance is $\leq 150^{\circ} \mathrm{Ch}$.

\section{CONCLUSION}

We have measured indoor temperatures in 17 dwellings in 16 new apartment buildings during a three month summertime period from 1 July to 31 August 2014. Results show that in several cases room temperatures did rise as high as $+32{ }^{\circ} \mathrm{C}$ and majority of the dwellings were experiencing temperatures over $+27^{\circ} \mathrm{C}$ for a remarkable portion of the measuring period, indicating high risk of overheating.

For summer thermal comfort compliance assessment of the studied buildings, we simulated indoor temperatures in the chosen dwellings most likely to counter overheating problems. We used indoor environment and energy simulation software IDA-ICE and climatic data from the Estonian Test Reference Year with input parameters for internal heat loads and usage profiles as defined in Estonian regulation No. 63 
"Methodology for calculating the energy performance of buildings" [8]. In total, 75 dwellings in 16 buildings were simulated.

The simulation results show that 13 out of 16 , i.e. $81.3 \%$ of the studied apartment buildings do not comply with the summer thermal comfort requirements of Estonian regulation No. 68 "Minimum requirements for energy performance" [7].

\section{ACKNOWLEDGEMENT}

This research has been conducted within European Intelligent Energy Europe IEE programme project QualiCheck: http://qualicheck-platform.eu/ "Towards improved compliance and quality of the works for better performing buildings".

\section{REFERENCES}

[1] EU, "Directive 2010/31/EU of the European Parliament and of the council of 19 May 2010 on the energy performance of buildings (recast)," Official Journal of the European Union, 18 June 2010 [Online]. Available: http://eur-lex.europa.eu [Acessed: 5. Nov 2014].

[2] K. M. S. Chvatal and H. Corvacho, "The impact of increasing the building envelope insulation upon the risk of overheating in summer and an increased energy consumption," Journal of Building Performance $\begin{array}{lllll}\text { Simulation, } & \text { vol. } & 2, & \text { pp. } & 267-282,\end{array}$ http://dx.doi.org/10.1080/19401490903095865

[3] D. P. Jenkins, V. Ingram, S. A. Simpson, and S. Patidar, "Methods for assessing domestic overheating for future building regulation compliance," Energy Policy, vol. 56, pp. 684-692, May 2013. http://dx.doi.org/10.1016/j.enpol.2013.01.030

[4] D. P. Jenkins, M. Gul, S. Patidar, P. F. G. Banfill, G. Gibson, and G. Menzies, "Designing a methodology for integrating industry practice into a probabilistic overheating tool for future building performance," Energy and Buildings, vol. 54, pp. 73-80, Nov 2012 http://dx.doi.org/10.1016/j.enbuild.2012.07.001

[5] T. Kalamees, S. Ilomets, R. Liias, L.-M. Raado, K. Kuusk, M. Maivel, et al., Eesti eluasemefondi ehitustehniline seisukord - ajavahemikul 19902010 kasutusele võetud korterelamud : uuringu lõpparuanne. Tallinn: Tallinna Tehnikaülikooli Kirjastus, 2012.

[6] M. Maivel, J. Kurnitski, and T. Kalamees, "Field survey of overheating problems in Estonian apartment buildings," Architectural Science Review, pp. 1-10, 2014.

[7] Ministry of Economic Affairs and Communications, "Ordinance No. 68 Minimum requirements for energy performance," RT I, 24.01.2014, 7 2014, [Online]. Available: https://www.riigiteataja.ee/en/eli/ 520102014001/ [Acessed: 15. Aug 2014].

[8] Ministry of Economic Affairs and Communications, "Ordinance No. 63, Methodology for calculating the energy performance of buildings," Ministry of Economic Affairs and Communications, RT I, 18.10.2012, 1, 2012, [Online]. Available: www.riigiteataja.ee/en/eli/520102014002/ consolide [Acessed: 5. Nov 2014].

[9] T. Kalamees and J. Kurnitski, "Estonian test reference year for energy calculations," Proceedings of the Estonian Academy of Sciences. Engineering, vol. 12, pp. 40-58, 2006.

[10] EQUA, IDA Indoor Climate and Energy 4.6.1. Equa Simulations AB, Available: www.equa.se, 2014

[11] S. Kropf and G. Zweifel, "Validation of the Building Simulation Program IDA-ICE According to CEN 13791 „Thermal Performance of Buildings - Calculation of Internal Temperatures of a Room in Summer Without Mechanical Cooling - General Criteria and Validation Procedures"," HLK Engineering, Hochschule Technik, Architektur Luzern. 2002

[12] Estonian Registry of Buildings database [Online]. Available: www.ehr.ee [Acessed: 3. Dec 2014].

[13] Estonian Land Board Map Server [Online]. Available: http://geoportaal.maaamet.ee/eng/ [Acessed: 11. Nov 2014].

[14] G. M. Heisler, "Effects of Individual Trees on the Solar-Radiation Climate of Small Buildings," Urban Ecology, vol. 9, pp. 337-359, Jun 1986. http://dx.doi.org/10.1016/0304-4009(86)90008-2 